\title{
Faktor Risiko yang Mempengaruhi Kejadian Malaria Di Indonesia : Review Literatur 2016-2020
}

\section{Risk Factors Affecting the Incidence of Malaria in Indonesia: A Literature Review 2016-2020}

\author{
Maurend Yayank Lewinsca ${ }^{\mathrm{a}}$, Mursid Raharjo ${ }^{\mathrm{b}}$, Nurjazuli $^{\mathrm{b}}$ \\ ${ }^{a}$ Magister Kesehatan Lingkungan Fakultas Kesehatan Masyarakat Universitas Diponegoro, Semarang \\ b. Dosen Magister Kesehatan Lingkungan Fakultas Kesehatan Masyarakat Universitas Diponegoro, Semarang
}

\section{A B S T R A C T/A B S T R A K}

\begin{abstract}
Malaria is a disease that is still a world health problem, in 2019 the number of malaria cases reached 229 million people. Indonesia is a developing region with a tropical and subtropical climate that is favored by Anopheles sp. Mosquitoes as their habitat. Malaria cases in Indonesia have increased based on the indicator of Annual Parasite Incidence (API) malaria and outbreaks (KLB) in several endemic areas. The purpose of this study was to determine the factors that influence the incidence of malaria in Indonesia by using literature studies in the last 5 years (2016-2020). The method used was a literature review with a literature search component, inclusion exclusion criteria, and study selection and quality assessment. The number of samples of this study were 22 samples of research articles. The results showed that there are several factors that most dominate the incidence of malaria in Indonesia, namely the use of mosquito nets (11 articles), the presence of breeding places (9 articles), the habit of going out at night (9 articles), and the use of mosquito repellents (5 articles). It is hoped that people in malaria endemic areas can use mosquito nets at night, always clean standing water around the house, avoid outdoor activities at night if not needed, and can avoid mosquito bites by using mosquito repellent.
\end{abstract}

Keywords:Malaria, Risk Factors, Anopheles sp.

\begin{abstract}
Malaria merupakan penyakit yang masih menjadi masalah kesehatan dunia, pada tahun 2019 angka kasus malaria mencapai 229 juta jiwa. Indonesia merupakan wilayah berkembang dengan iklim tropis dan subtropis yang disukai nyamuk Anopheles sp. sebagai habitat tempat tinggalnya. Kasus malaria di Indonesia mengalami peningkatan berdasarkan indikator Annual Parasite Incidence (API) malaria dan kejadian luar biasa (KLB) di beberapa daerah endemis. Tujuan penelitian ini adalah untuk mengetahui faktor-faktor yang mempengaruhi kejadian malaria di Indonesia dengan menggunakan studi literature dalam kurun waktu 5 tahun terakhir (2016-2020). Metode yang digunakan adalah review literature dengan dengan komponen pencarian literatur, kriteria inklusi eksklusi, dan seleksi studi dan penilaian kualitas. Jumlah sampel penelitian ini adalah 22 sampel artikel penelitian. Hasil penelitian menunjukkan terdapat beberapa faktor yang paling dominan mempengaruhi kejadian malaria di Indonesia yaitu penggunaan kelambu (11 artikel), keberadaan breeding place ( 9 artikel), kebiasaan keluar rumah pada malam hari ( 9 artikel), dan penggunaan obat anti nyamuk (5 artikel). Diharapkan masyarakat di daerah endemis malaria untuk dapat menggunakan kelambu pada malam hari, selalu membersihkan genangan air disekitar rumah, menghindari aktivitas keluar pada malam hari jika tidak diperlukan, serta dapat menghindari gigitan nyamuk dengan penggunaan obat anti nyamuk.
\end{abstract}

Kata Kunci : Malaria, Faktor Risiko, Anopheles sp.

Copyright $(9) 2021$ Jurnal Kesehatan Lingkungan

All right reserved

*Alamat korespondensi : email : maurendyl@gmail.com

\section{PENDAHULUAN}

Malaria masih menjadi masalah kesehatan, diperkirakan dua pertiga kematian terjadi pada anakanak di bawah usia lima tahun. Pada tahun 2019 data yang dikumpulkan sebanyak 229 juta kasus malaria di seluruh dunia dengan perkiraan jumlah kematian akibat malaria mencapai 409.000 jiwa. $^{1}$

Saat ini program malaria dihadapkan pada tantangan perubahan epidemiologi. Peningkatan proporsi malaria yang diimpor dan kelompok berisiko tinggi tidak lagi anak-anak dan ibu hamil 
tetapi lebih terkait dengan risiko faktor demografis dan pekerjaan khusus dalam lingkup lokal. ${ }^{2}$ Malaria umumnya ditemukan di tempat-tempat terpencil atau sulit dijangkau tepatnya di negara dengan ekonomi rendah dan berkembang. Malaria menjadi salah satu indikator Agenda 2030 Tujuan Pembangunan Berkelanjutan (TPB) atau Sustainable Development Goals (SDGs) untuk mengeleminasi epidemi malaria pada tahun $2030 .^{3}$

Di Indonesia, Annual Parasite Incidence (API) malaria pada tahun 2019 meningkat dibandingkan tahun 2018, yaitu dari yang awalnya sebesar 0,84 menjadi 0,93 per 1.000 penduduk. ${ }^{4}$ Capaian eliminasi tingkat kabupaten atau kota pada tahun 2019 adalah sebanyak 300 kabupaten atau kota sedangkan untuk eliminasi tingkat provinsi belum ada yang mencapai, meskipun terdapat 3 provinsi yang seluruh kabupaten atau kotanya telah mencapai eliminasi. $^{5}$

Berdasarkan penelitian terdahulu diperoleh data kejadian Malaria di Indonesia pada tahun 2013 bahwa 5 provinsi yang memiliki angka insiden dan prevalensi tertinggi yaitu Provinsi Papua (9,8\% dan $28,6 \%)$, Provinsi Nusa Tenggara Timur $(6,8 \%$ dan 23,3\%), Provinsi Papua Barat (6,7\% dan 19,4\%), Provinsi Sulawesi Tengah (5,1\% dan 12,5\%), dan Provinsi Maluku (3,8\% dan 10,7\%) berdasarkan Data Riset Kesehatan Dasar. ${ }^{6}$ Provinsi Papua merupakan daerah dengan kasus malaria tertinggi setiap tahunnya dan memiliki angka Annual Parasite Incidence (API) 41,31 per 1000 penduduk pada tahun 2018. ${ }^{7}$ Angka kesakitan malaria di Puskesmas Moru Provinsi Nusa Tenggara Timur pada tahun 2014 dengan Annual Parasite Incident (API) sebesar $16,9 \% .{ }^{8}$ Provinsi Sulawesi Tengah pada tahun 2014 terdapat 4.211 kasus malaria dan penelitian yang dilakukan di Puskesmas Kampung Baru Wuluk diperoleh hasil statistik bahwa tingkat pendidikan, tindakan pencegahan dan sikap berhubungan signifikan terhadap kejadian malaria. ${ }^{9}$ Penelitian lain yang dilakukan di Kecamatan Seram Provinsi Maluku menunjukkan suhu, kelembaban, kepadatan Anopheles sp., dan jarak tempat perindukan nyamuk berpengaruh terhadap kejadian malaria. ${ }^{10}$

Indonesia juga termasuk daerah berkembang dengan iklim tropis dan sub tropis yaitu sebagai habitat yang disukai nyamuk Anopheles sp. vektor penyebab penyakit malaria. Penyakit ini dapat menginfeksi semua kelompok umur. Meningkatnya angka kejadian malaria dipengaruhi oleh faktor perubahan iklim terkait lingkungan fisik, kimiawi, biologis dan social serta perilaku masyarakat. ${ }^{11}$

Permasalahan malaria yang terus berkembang di Indonesia terkait dengan masih lemahnya upaya penurunan angka kejadian malaria seperti keberadan breeding place (tempat berkembang biak) nyamuk anopheles yang menyebar dan lokasi yang sulit untuk di jangkau, kondisi lingkungan rumah yang tidak memenuhi syarat kesehatan (ventilasi, atap plafon, dinding rumah yang belum memadai), perilaku masyarakat melakukan aktivitas keluar rumah pada malam hari dan menjelang subuh (menyadap karet). ${ }^{12}$ Selain itu beberapa jurnal menyebutkan bahwa terdapat pula faktor demografi, kebersihan lingkungan, dan sosial ekonomi yang dapat mempengaruhi kejadian malaria di Indonesia. Oleh karena itu peneliti ingin mengetahui lebih jauh faktor-faktor yang mempengaruhi kejadian malaria di Indonesia dengan menggunakan studi literature dalam kurun waktu 5 tahun terakhir (2016-2020).

\section{BAHAN DAN METODE}

Metode dalam penelitian ini adalah literature review. Literature review merupakan uraian tentang teori, temuan dan bahan penelitian lain yang diperoleh dari bahan acuan untuk dijadikan landasan dalam penelitian. ${ }^{13}$ Pencarian literature menggunakan database akademik yaitu ProQuest, Science Direct, Research Gate, dan Google Scholar. Jumlah artikel yang masuk dalam sampel penelitian adalah 22 artikel.

Metode penulisan artikel ini berdasarkan literature review terdiri dari beberapa beberapa komponen, antara lain : ${ }^{14}$

\section{Pencarian Literatur}

a. Menggunakan database akademik yaitu ProQuest, Science Direct, Research Gate, dan Google Scholar.

b. Jumlah artikel yang direview 22 artikel dalam 5 tahun terakhir (2016-2020)

c. Pencarian artikel menggunakan kata kunci "faktor risiko malaria di Indonesia, faktor risiko malaria, faktor perilaku dan lingkungan yang mempengaruhi kejadian malaria, determinan kejadian malaria di Indonesia, risk factors of malaria, environmental risk factors of malaria in Indonesia"

\section{Kriteria Inklusi dan Eksklusi}

Kriteria Inklusi adalah semua aspek yang harus ada dalam sebuah penelitian. Sedangkan kriteria eksklusi adalah faktor-faktor yang dapat menyebabkan sebuah penelitian menjadi tidak layak 
untuk di review. Kriteria inklusi dalam penelitian ini sebagai berikut :

a. Artikel penelitian nasional dan internasional yang mengkaji faktor (lingkungan, perilaku, sosial ekonomi, demografi, karakteristik individu) yang mempengaruhi kejadian malaria di Indonesia

b. Artikel penelitian diterbitkan dalam rentang tahun 2016-2020

c. Tipe artikel penelitian research articles (desain penelitian case control dan cross sectional).

d. Artikel penelitian yang dapat diakses secara penuh (full text).

Adapun Kriteria eksklusi dalam penelitian ini adalah : a. Studi kasus lokasi penelitian faktor malaria di Luar Negeri

b. Artikel penelitian diterbitkan sebelum tahun 2016 ataupun setelah tahun 2020.

\section{Seleksi Studi dan Penilaian Kualitas}

Langkah pertama dalam seleksi studi adalah melakukan screening abstrak dan diikuti dengan screening teks lengkap. Artikel atau studi yang tidak relevan bisa dikeluarkan dengan mempertimbangkan relevansi dan kesesuaian dengan ruang lingkup tujuan penelitian. Langkahlangkah review seperti penentuan topic, pencarian pustaka, pemilihan oustaka yang relevan, analisa artikel dan penyusunan review.

HASIL

Tabel 1. Hasil kajian literatur artikel

\begin{tabular}{|c|c|c|c|c|c|c|}
\hline No. & Penulis & Tujuan & Metode & Sampel & Variabel & Hasil \\
\hline 1. & $\begin{array}{l}\text { Pratiwi Ika } \\
\text { Noviarti, } \\
\text { Tri Joko, } \\
\text { Nikie } \\
\text { Astorina } \\
\text { Yunita } \\
\text { Dewanti } \\
(2016)^{15}\end{array}$ & $\begin{array}{l}\text { Penelitian ini } \\
\text { bertujuan } \\
\text { untuk } \\
\text { menganalisis } \\
\text { hubungan } \\
\text { lingkungan } \\
\text { fisik dan } \\
\text { perilaku } \\
\text { warga dengan } \\
\text { kejadian luar } \\
\text { biasa } \\
\text { penyakit } \\
\text { malaria di } \\
\text { wilayah kerja } \\
\text { Puskesmas } \\
\text { Kokap II. }\end{array}$ & $\begin{array}{l}\text { Desain } \\
\text { penelitian } \\
\text { Observasiona } \\
\text { 1, pendekatan } \\
\text { yang } \\
\text { digunakan } \\
\text { yakni desain } \\
\text { studi case } \\
\text { control }\end{array}$ & $\begin{array}{l}\text { Jumlah sampel } \\
\text { dalam } \\
\text { penelitian ini } \\
\text { adalah } 74 \\
\text { responden } \\
\text { dengan } \\
\text { perbandingan } \\
\text { kasus dan } \\
\text { kontrol 1:1 (37 } \\
\text { kasus dan } 37 \\
\text { kontrol). }\end{array}$ & 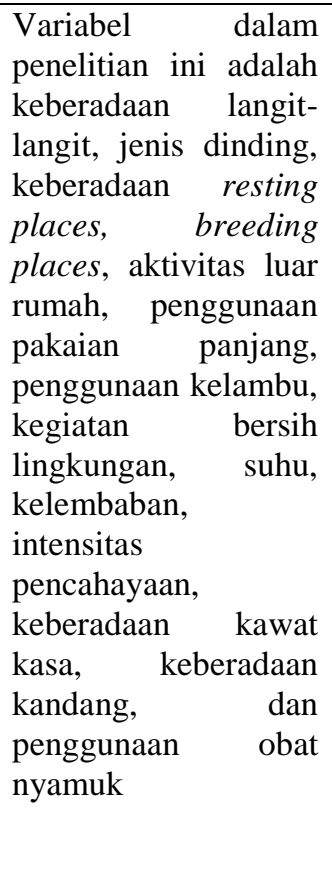 & 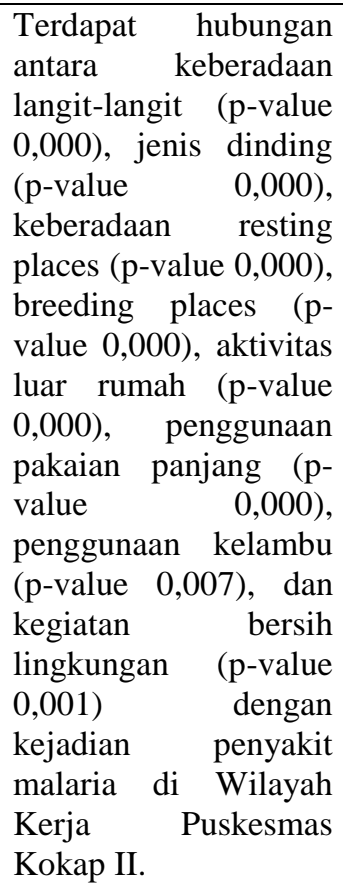 \\
\hline 2. & $\begin{array}{l}\text { Sudirman } \\
\text { Manumpa } \\
(2016)^{8}\end{array}$ & $\begin{array}{l}\text { Tujuan } \\
\text { penelitian ini } \\
\text { adalah untuk } \\
\text { menganalisis } \\
\text { faktor yang } \\
\text { memengaruhi } \\
\text { kejadian } \\
\text { malaria di } \\
\text { wilayah kerja } \\
\text { Puskesmas } \\
\text { Moru Kecamatan } \\
\text { Alor Barat }\end{array}$ & $\begin{array}{l}\text { Jenis } \\
\text { penelitian ini } \\
\text { merupakan } \\
\text { penelitian } \\
\text { analitik } \\
\text { observasional } \\
\text {. Rancangan } \\
\text { penelitian } \\
\text { yang } \\
\text { digunakan } \\
\text { adalah cross } \\
\text { sectional. }\end{array}$ & $\begin{array}{l}\text { Besar sampel } \\
\text { dalam } \\
\text { penelitian ini } \\
\text { adalah } 173 \\
\text { sampel yang } \\
\text { diambil dari } \\
\text { populasi } \\
\text { pasien yang } \\
\text { melakukan } \\
\text { kunjungan ke } \\
\text { unit } \\
\text { laboratorium } \\
\text { Puskesmas }\end{array}$ & $\begin{array}{l}\text { Variabel dalam } \\
\text { penelitian ini adalah } \\
\text { faktor demografi } \\
\text { berupa jenis kelamin, } \\
\text { umur, status sosial } \\
\text { ekonomi, risiko } \\
\text { pekerjaan, tingkat } \\
\text { pendidikan dan faktor } \\
\text { riwayat pernah } \\
\text { menderita malaria } \\
\text { sebelumnya. }\end{array}$ & $\begin{array}{l}\text { Pada faktor demografi } \\
\text { diperoleh hasil bahwa } \\
\text { terdapat pengaruh } \\
\text { antara umur, status } \\
\text { sosial ekonomi dan } \\
\text { tingkat pendidikan } \\
\text { dengan kejadian } \\
\text { malaria. } \\
\text { dominan Faktor } \\
\text { memengaruhi kejadian } \\
\text { malaria adalah status } \\
\text { sosial ekonomi rendah } \\
\text { dan umur 25-76 }\end{array}$ \\
\hline
\end{tabular}




\begin{tabular}{|c|c|c|c|c|c|c|}
\hline & & $\begin{array}{l}\text { Daya, } \\
\text { Kabupaten } \\
\text { Alor. }\end{array}$ & & $\begin{array}{l}\text { Moru untuk } \\
\text { melakukan } \\
\text { pemeriksaan } \\
\text { darah tepi } \\
\text { dengan } \\
\text { mikroskop } \\
\text { maupun } \\
\text { dengan RDT } \\
\text { pada bulan } \\
\text { Juni sampai } \\
\text { dengan } \\
\text { Oktober tahun } \\
\text { 2015. }\end{array}$ & & tahun. \\
\hline 3. & $\begin{array}{l}\text { Fadjar } \\
\text { Harry } \\
\text { Wiwoho, } \\
\text { Suharyo } \\
\text { Hadisaputr } \\
\text { o, Ari } \\
\text { Suwondo } \\
(2016)^{16}\end{array}$ & $\begin{array}{l}\text { Penelitian ini } \\
\text { bertujuan } \\
\text { untuk } \\
\text { mengetahui } \\
\text { faktor risiko } \\
\text { yang } \\
\text { mempengaru } \\
\text { hi Kejadian } \\
\text { Malaria }\end{array}$ & $\begin{array}{l}\text { Jenis } \\
\text { penelitian ini } \\
\text { adalah } \\
\text { penelitian } \\
\text { observasional } \\
\text { dengan } \\
\text { menggunakan } \\
\text { case control } \\
\text { study dan } \\
\text { dipertajam } \\
\text { dengan data } \\
\text { kualitatif } \\
\text { melalui } \\
\text { wawancara } \\
\text { mendalam } \\
\text { (indept } \\
\text { interview). }\end{array}$ & $\begin{array}{l}\text { Sampel } \\
\text { penelitian ini } \\
\text { berjumlah } 152 \\
\text { orang yang } \\
\text { terdiri atas } 76 \\
\text { kelompok } \\
\text { kasus dan } 76 \\
\text { kelompok } \\
\text { kontrol. } \\
\text { Adapun teknik } \\
\text { yang } \\
\text { digunakan } \\
\text { dalam } \\
\text { penentuan } \\
\text { sampel adalah } \\
\text { purposive } \\
\text { sampling }\end{array}$ & $\begin{array}{l}\text { Variabel dalam } \\
\text { penelitian ini adalah } \\
\text { status gizi, kebiasaan } \\
\text { keluar rumah pada } \\
\text { malam hari, } \\
\text { kebiasaan } \\
\text { menggunakan } \\
\text { kelambu, kebiasaan } \\
\text { menggunakan obat } \\
\text { nyamuk, keadaan } \\
\text { langit rumah, } \\
\text { keadaan dinding } \\
\text { rumah, adanya } \\
\text { selokan, adanya } \\
\text { kolam, adanya } \\
\text { semak-semak, dan } \\
\text { riwayat tinggal di } \\
\text { daerah endemis. }\end{array}$ & $\begin{array}{l}\text { Penelitian ini } \\
\text { menunjukkan bahwa } \\
\text { kebiasaan } \\
\text { menggunakan } \\
\text { kelambu, keadaan } \\
\text { langit rumah, dan } \\
\text { keberadaan selokan di } \\
\text { sekitar lingkungan } \\
\text { rumah merupakan } \\
\text { faktor risiko kejadian } \\
\text { malaria. }\end{array}$ \\
\hline 4. & $\begin{array}{l}\text { Ahmad } \\
\text { Faizal } \\
\text { Rangkuti, } \\
\text { Sulistyani, } \\
\text { Nur Endah } \\
\text { W }(2017)^{17}\end{array}$ & $\begin{array}{l}\text { Penelitian ini } \\
\text { bertujuan } \\
\text { untuk } \\
\text { mengetahui } \\
\text { faktor } \\
\text { lingkungan } \\
\text { dan perilaku } \\
\text { yang } \\
\text { berhubungan } \\
\text { dengan } \\
\text { kejadian } \\
\text { malaria. }\end{array}$ & $\begin{array}{l}\text { Penelitian ini } \\
\text { termasuk } \\
\text { jenis } \\
\text { observasional } \\
\text { dengan desain } \\
\text { penelitian } \\
\text { yang dipakai } \\
\text { adalah case } \\
\text { control. }\end{array}$ & $\begin{array}{l}\text { Besar sampel } \\
\text { dalam } \\
\text { penelitian ini } \\
\text { adalah } 132 \\
\text { responden } \\
\text { yang terdiri } \\
\text { dari } 66 \text { kasus } \\
\text { dan } 66 \text { kontrol }\end{array}$ & $\begin{array}{l}\text { Variabel } \\
\text { penelitian ini adalah } \\
\text { kebiasaan } \\
\text { penggunaan kelambu, } \\
\text { penggunaan obat anti } \\
\text { nyamuk, kebiasaan } \\
\text { keluar rumah pada } \\
\text { malam hari, } \\
\text { kerapatan pakaian } \\
\text { keluar rumah pada } \\
\text { malam hari, } \\
\text { keberadaan genangan } \\
\text { air dan keberadaan } \\
\text { kawat kasa pada } \\
\text { ventilasi rumah. }\end{array}$ & 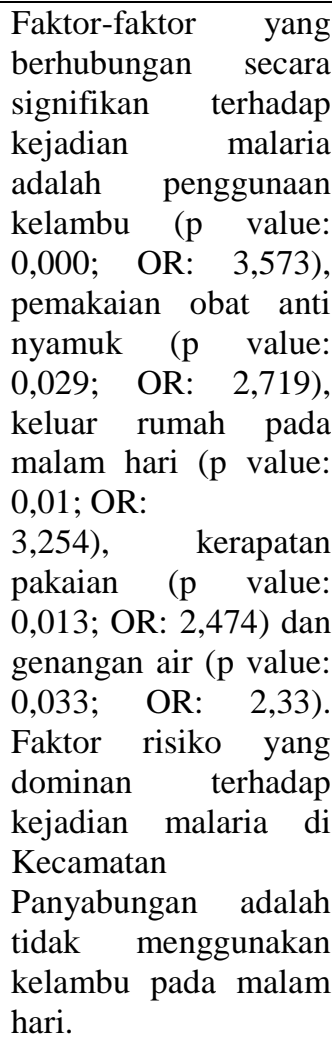 \\
\hline 5. & $\begin{array}{l}\text { Wardah, } \\
\text { Nurjazuli, }\end{array}$ & $\begin{array}{l}\text { Penelitian ini } \\
\text { bertujuan }\end{array}$ & $\begin{array}{l}\text { Penelitian ini } \\
\text { bersifat }\end{array}$ & $\begin{array}{l}\text { Sampel } \\
\text { penelitian ini }\end{array}$ & $\begin{array}{l}\text { Keberadaan kandang } \\
\text { ternak, keberadaan }\end{array}$ & $\begin{array}{ll}\text { Ada } & \text { hubungan } \\
\text { kebiasaan berada di }\end{array}$ \\
\hline
\end{tabular}




\begin{tabular}{|c|c|c|c|c|c|c|}
\hline & $\begin{array}{l}\text { Hanan } \\
\text { Lanang } \\
\text { Dangiran } \\
(2017)^{18}\end{array}$ & $\begin{array}{l}\text { untuk } \\
\text { menganalisis } \\
\text { hubungan } \\
\text { antara faktor } \\
\text { lingkungan } \\
\text { dengan } \\
\text { penyakit } \\
\text { malaria di } \\
\text { wilayah } \\
\text { Puskesmas } \\
\text { Salaman I } \\
\text { dengan } \\
\text { menggunakan } \\
\text { pendekatan } \\
\text { spasial }\end{array}$ & $\begin{array}{l}\text { observasional } \\
\text { analitik } \\
\text { dengan desain } \\
\text { studi case } \\
\text { control. }\end{array}$ & $\begin{array}{l}\text { sebanyak } \\
\text { adalah } \\
\text { responden. } \\
\text { Dengan } \\
\text { orang } \\
\text { kelompok } \\
\text { kasus } \\
\text { dan } 54 \text { orang } \\
\text { kelompok } \\
\text { kontrol. } \\
\text { Pengambilan } \\
\text { sampel dengan } \\
\text { teknik } \\
\text { purposive } \\
\text { sampling. }\end{array}$ & $\begin{array}{l}\text { breeding place, } \\
\text { keberadaan resting } \\
\text { place, kebiasaan } \\
\text { berada di luar rumah } \\
\text { pada malam hari, } \\
\text { penggunaan kelambu, } \\
\text { penggunaan obat anti } \\
\text { nyamuk, penggunaan } \\
\text { kawat kasa. }\end{array}$ & $\begin{array}{l}\text { luar rumah pada } \\
\text { malam hari dan } \\
\text { penggunaan kelambu } \\
\text { dengan } \\
\text { malaria di wejadian } \\
\text { kerja } \\
\text { Puskesmas Salaman I, } \\
\text { Kabupaten } \\
\text { Magelang. }\end{array}$ \\
\hline 6. & $\begin{array}{l}\text { Darmiah, } \\
\text { Baserani, } \\
\text { Abdul } \\
\text { Khair, } \\
\text { Isnawati, } \\
\text { dan } \\
\text { Yuniarti } \\
\text { Suryatinah } \\
(2017)^{19}\end{array}$ & $\begin{array}{l}\text { Penelitian } \\
\text { bertujuan } \\
\text { untuk } \\
\text { mengetahui } \\
\text { hubungan } \\
\text { tingkat } \\
\text { pengetahuan } \\
\text { dan pola } \\
\text { perilaku } \\
\text { dengan } \\
\text { kejadian } \\
\text { malaria di } \\
\text { Kabupaten } \\
\text { Katingan } \\
\text { Provinsi } \\
\text { Kalimantan } \\
\text { Tengah }\end{array}$ & $\begin{array}{l}\text { Penelitian } \\
\text { bersifat } \\
\text { analitik } \\
\text { dengan } \\
\text { rancangan } \\
\text { penelitian } \\
\text { case control. }\end{array}$ & $\begin{array}{l}\text { Sampel } \\
\text { penelitian } \\
\text { berjumlah } 58 \\
\text { responden } \\
\text { dengan } \\
\text { perbandingan } \\
\text { kasus 29 dan } \\
\text { kontrol } 29 \\
(1: 1) .\end{array}$ & $\begin{array}{l}\text { Tingkat pengetahuan } \\
\text { dan pola perilaku } \\
\text { tentang malaria. }\end{array}$ & $\begin{array}{l}\text { Tingkat pengetahuan } \\
\text { dan pola perilaku } \\
\text { merupakan faktor } \\
\text { risiko kejadian malaria } \\
\text { di wilayah kerja } \\
\text { Puskesmas Kasongan } \\
\text { Kecamatan Katingan } \\
\text { Hilir Kabupaten } \\
\text { Katingan dengan Odds } \\
\text { Ratio sebesar } 2,45 \text { kali } \\
\text { dan 9,28 kali pada CI } \\
\text { 95\% (2.291-37.638). }\end{array}$ \\
\hline 7. & $\begin{array}{l}\text { Abner Fritz } \\
\text { Watofa, } \\
\text { Adi Heru } \\
\text { Husodo, } \\
\text { Sudarmadji } \\
\text { dan Onny } \\
\text { Setiani } \\
(2017)^{20}\end{array}$ & $\begin{array}{l}\text { Tujuan dalam } \\
\text { penelitian ini } \\
\text { adalah untuk } \\
\text { mengetahui } \\
\text { dan } \\
\text { menganalisis } \\
\text { hubungan } \\
\text { antara faktor } \\
\text { risiko } \\
\text { lingkungan } \\
\text { fisik yang } \\
\text { terdiri dari } \\
\text { suhu, } \\
\text { kelembaban, } \\
\text { curah hujan, } \\
\text { kondisi air, } \\
\text { ketinggian, } \\
\text { lahan, dan } \\
\text { kondisi } \\
\text { tempat } \\
\text { tinggal } \\
\text { dengan kejadian } \\
\text { malaria di } \\
\text { wilayah } \\
\text { Danau }\end{array}$ & $\begin{array}{l}\text { Pendekatan } \\
\text { penelitian } \\
\text { cross } \\
\text { sectional } \\
\text { dengan jenis } \\
\text { penelitian } \\
\text { observasi } \\
\text { analitik }\end{array}$ & $\begin{array}{l}\text { Populasi } \\
\text { dalam } \\
\text { penelitian ini } \\
\text { adalah seluruh } \\
\text { penduduk di } \\
\text { Distrik } \\
\text { Sentani. } \\
\text { Sampel } \\
\text { penelitian } \\
\text { sebanyak } 200 \\
\text { orang. }\end{array}$ & $\begin{array}{l}\text { Faktor lingkungan } \\
\text { fisik } \\
\text { kelembaban, } \\
\text { hujan, pH } \\
\begin{array}{l}\text { curah } \\
\text { ketinggian, }\end{array} \\
\text { penggunaan } \\
\begin{array}{l}\text { dan kondisi } \\
\text { rumah) }\end{array}\end{array}$ & $\begin{array}{lr}\text { Faktor } & \text { lingkungan } \\
\text { fisik } & \text { memiliki } \\
\text { hubungan } & \text { yang } \\
\text { bermakna } & \text { dengan } \\
\text { kajadian } & \text { malaria } \\
\text { dengan nilai } & \text { Chi- } \\
\text { Square sebesar } 7,531 \\
\text { (p=0.006) rasio regresi } \\
\text { logistik dengan nilai } \\
\text { OR sebesar 4,132 (p = } \\
0,009>0,05) \text {. }\end{array}$ \\
\hline
\end{tabular}




\begin{tabular}{|c|c|c|c|c|c|c|}
\hline \multirow[b]{2}{*}{8.} & \multicolumn{3}{|c|}{ Sentani. } & \multirow[b]{2}{*}{$\begin{array}{l}\text { Populasi } \\
\text { sampel sampel } \\
\text { berjumlah } 90 \\
(1: 2) \text { dengan } \\
30 \text { responden } \\
\text { sampel kasus } \\
\text { dan sampel } \\
\text { kontrol } \\
\text { sebanyak } 60 \\
\text { responden } \\
\text { dengan cara } \\
\text { simple random } \\
\text { sampling. }\end{array}$} & \multirow[b]{2}{*}{$\begin{array}{l}\text { Variabel } \\
\text { penelitian ini adalah } \\
\text { pekerjaan, } \\
\text { pendidikan, } \\
\text { pendapatan, jarak } \\
\text { rumah, kandang } \\
\text { ternak, genangan air, } \\
\text { penggunaan kawat } \\
\text { kasa, jenis dinding } \\
\text { rumah, penggunaan } \\
\text { kelambu, penggunaan } \\
\text { obat anti nyamuk, } \\
\text { dan keluar rumah } \\
\text { pada malam hari }\end{array}$} & \multirow[b]{2}{*}{$\begin{array}{l}\text { Faktor risiko yang } \\
\text { berpengaruh tehadap } \\
\text { kejadian malaria } \\
\text { adalah genangan air } \\
\text { ( } \rho \text {-value }=0,056) \text {, } \\
\text { penggunaan kawat } \\
\text { kasa ( } \rho \text {-value=0.021) } \\
\text { jenis dinding rumah } \\
(\rho \text {-value=0,021), } \\
\text { penggunaan kelambu } \\
(\rho \text {-value=0,009), } \\
\text { penggunaan oba } \\
\text { nyamuk malaria } \\
(\rho v a l u e=0.020) \text {, dan } \\
\text { keluar rumah pada } \\
\text { malam } \\
(\rho \text { alue }=0,030) \text {. }\end{array}$} \\
\hline & $\begin{array}{l}\text { Andi Raya } \\
\text { Sarjatno, } \\
\text { AL } \\
\text { Rantetampa } \\
\text { ng, Sarce } \\
\text { Makaba, } \\
\text { Anwar } \\
\text { Mallongi } \\
(2018)^{21}\end{array}$ & $\begin{array}{l}\text { Tujuan } \\
\text { penelitian ini } \\
\text { adalah untuk } \\
\text { mengetahui } \\
\text { faktor risiko } \\
\text { penyakit } \\
\text { malaria di } \\
\text { Puskesmas } \\
\text { Dawai } \\
\text { Kecamatan } \\
\text { Yapen Timur } \\
\text { Kabupaten } \\
\text { Kepulauan } \\
\text { Yapen. }\end{array}$ & $\begin{array}{l}\text { Penelitian } \\
\text { yang akan } \\
\text { dilakukan } \\
\text { merupakan } \\
\text { penelitian } \\
\text { observasional } \\
\text { dengan } \\
\text { menggunakan } \\
\text { case control } \\
\text { study. }\end{array}$ & & & \\
\hline 9. & $\begin{array}{l}\text { Resiany } \\
\text { Nababan } \\
\text { dan Sitti } \\
\text { Rahmah } \\
\text { Umniyati } \\
(2018)^{22}\end{array}$ & $\begin{array}{l}\text { Penelitian ini } \\
\text { bertujuan } \\
\text { untuk } \\
\text { menganalisis } \\
\text { faktor risiko } \\
\text { penyakit } \\
\text { malaria, } \\
\text { memetakan } \\
\text { sebaran } \\
\text { spasial kasus } \\
\text { malaria } \\
\text { terkait } \\
\text { kebiasaan } \\
\text { perkembangb } \\
\text { iakan hingga } \\
\text { jarak lokasi } \\
\text { dan } \\
\text { mengetahui } \\
\text { habitat } \\
\text { Anopheles } \\
\text { sp. Jentik- } \\
\text { jentik } \\
\text { nyamuk di } \\
\text { dekat puskesmas } \\
\text { Winong, } \\
\text { kabupaten } \\
\text { Purworejo. }\end{array}$ & $\begin{array}{l}\text { Penelitian ini } \\
\text { merupakan } \\
\text { penelitian } \\
\text { case control } \\
\text { dengan } \\
\text { menggunakan } \\
\text { data melalui } \\
\text { sistem } \\
\text { informasi } \\
\text { geografi yang } \\
\text { terkait dengan } \\
\text { kejadian } \\
\text { malaria. }\end{array}$ & $\begin{array}{l}\text { Pengambilan } \\
\text { sampel secara } \\
\text { total } \\
\text { berdasarkan } \\
\text { kriteria inklusi } \\
\text { dan eksklusi } \\
\text { peneliti. } \\
\text { Perbandingan } \\
\text { sampel } 1: 2 \\
\text { dengan } 40 \\
\text { kasus dan } 80 \\
\text { kontrol }\end{array}$ & $\begin{array}{lr}\begin{array}{l}\text { Suhu, } \\
\text { curah, } \\
\text { habitat }\end{array} & \text { keberadaan } \\
\text { perkembangbiakan, } & \\
\text { kondisi } & \text { dinding } \\
\text { rumah, } & \text { kebiasaan } \\
\text { malam } & \text { hari, } \\
\text { keberadaan } & \text { ternak, } \\
\text { jarak } & \text { tempat } \\
\text { berkembang } & \text { biak, } \\
\text { kebiasaan memakai } & \text { melambu, penggunaan } \\
\text { jaring } & \text { kawat, } \\
\text { penggunaan } & \text { obat } \\
\text { nyamuk bakar dan } \\
\text { kebiasaan berkunjung } \\
\text { ke daerah endemis. }\end{array}$ & $\begin{array}{l}\text { Hasil penelitian } \\
\text { menunjukkan bahwa } \\
\text { ada hubungan antara } \\
\text { keberadaan habitat } \\
\text { perkembangbiakan, } \\
\text { kondisi dinding rumah } \\
\text { dan kebiasaan malam } \\
\text { hari kejadian malaria. } \\
\text { Kebiasaan di luar } \\
\text { malam merupakan } \\
\text { faktor risiko tertinggi }\end{array}$ \\
\hline 10. & $\begin{array}{l}\text { Sepriyani, } \\
\text { Andoko, } \\
\text { Agung Aji } \\
\text { Perdana } \\
(2018)^{23}\end{array}$ & $\begin{array}{l}\text { Tujuan } \\
\text { penelitian } \\
\text { adalah untuk } \\
\text { mengetahui } \\
\text { faktor risiko } \\
\text { kejadian } \\
\text { malaria di } \\
\text { Puskesmas } \\
\text { Rawat Inap } \\
\text { Biha } \\
\text { Kabupaten } \\
\text { Pesisir Barat } \\
\text { tahun 2017- }\end{array}$ & $\begin{array}{l}\text { Penelitian ini } \\
\text { merupakan } \\
\text { penelitian } \\
\text { observasional } \\
\text { menggunakan } \\
\text { desain case } \\
\text { control atau } \\
\text { retrospective } \\
\text { study. }\end{array}$ & $\begin{array}{lr}\text { Sampel yang } \\
\text { digunakan } \\
\text { dalam } \\
\text { penelitian ini } \\
\text { adalah } 123 \\
\text { kasus dan } & 123 \\
\text { kontrol atau } \\
\text { sebanyak } & 246 \\
\text { responden. } & \end{array}$ & $\begin{array}{lr}\text { Kandang } & \text { ternak, } \\
\text { tempat perindukan } \\
\text { nyamuk, } \\
\text { langit, dinding, kawat } \\
\text { kasa, dan pemakaian } \\
\text { kelambu. }\end{array}$ & $\begin{array}{l}\text { Hasil penelitian } \\
\text { menunjukkan ada } \\
\text { hubungan langit-langit } \\
\text { ( } \mathrm{p} \text { value } 0,000 \text {. OR } \\
8,04 \text { ), dinding (p value } \\
0,000 \text {. OR } 3,9 \text { ), kawat } \\
\text { kassa (p value 0,000 } \\
\text { OR 4,05), kelambu (p } \\
\text { value 0,000. OR 16,6) } \\
\text { dengan kejadian } \\
\text { malaria. Penggunaan } \\
\text { kelambu merupakan } \\
\text { faktor yang paling }\end{array}$ \\
\hline
\end{tabular}


11. Unun Tujuan dari Penelitian ini Total sampel Tingkat pendidikan, Hasil penelitian yang Budiarti M. penelitian ini merupakan dalam tindakan pencegahan, diperoleh bahwa penelitian ini faktor risiko malaria sikap, pekerjaan, dan Talombo, menganalisis analisis sebanyak 130 Muh. Ardi faktor risiko

Munir, utama

Gabriella kejadian

observasional yang terdiri

Lintin

Malaria

dengan

dari tingkat pengetahuan. $(2018)^{9}$

Wilayah di pendekatan penderita Malaria dan 67 Puskesmas Kampung sectional bukan penderita Malaria.

adalah pendidikan

6.11), tingkat pencegahan (OR: 4.04), dan sikap responden (OR: 2.65).

Baru Luwuk tahun 20132015.

12.

\begin{tabular}{lll}
\hline P & C & Tyanoer \\
& & Pen \\
$(2018)^{24}$ & &
\end{tabular}

Tujuan

Desain
penelitian
Observasiona
1, pendekatan
yang
digunakan
yakni desain
studi case
control

Keberadaan
73 kasus dan 73 kontrol (tetangga dalam jarak 10 meter)

\section{genangan air, dinding \\ rumah, ventilasi}

rumah, penggunaan jaring kawat, penggunaan obat anti nyamuk, kebiasaan $\begin{array}{lr}\text { Hasil } & \text { penelitian } \\ \text { terdapat } & \text { pengaruh } \\ \text { penggunaan } & \text { kelambu } \\ \text { (OR: } & 17,60) \text {, }\end{array}$ kebiasaan berada di luar rumah pada malam hari (OR: 14,37). Sedangkan keberadaan kandang ternak terhadap perumahan memiliki keterkaitan paling kecil (OR: 4,40).

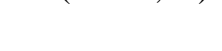
penelitian ini adalah untuk mengevaluasi faktor lingkungan apa saja yang dominan mempengaru hi kejadian malaria di wilayah kerja Puskesmas

Labuhan

Ruku Talawi

Batubara 146 orang dari berada diluar rumah pada malam hari, penggunaan kelambu, kebiasaan menggantung pakaian, keberadaan kandang ternak, minum obat sesuai anjuran, dan kesediaan pelayanan kesehatan

13.

\begin{tabular}{llll}
\hline Efraim & Menganalisis & Jenis & Jumlah sampel \\
Watmanlus & secara spasial & penelitian ini & dalam \\
y, Mursid & karakteritik & adalah & penelitian ini \\
Raharjo, & linkungan & observasional & adalah 100 \\
Nurjazuli & dan dinamika & analitik, & orang dengan \\
$(2019)^{10}$ & kepadatan & desain studi & teknik \\
& Anopheles sp. cross & purposive \\
& Kaitannya & sectional & sampling. \\
& dengan & & \\
kejadian & & \\
& malaria di & & \\
& Kecamatan & & \\
& Seram Barat. & &
\end{tabular}

kelembaban, udara

kepadatan Anopheles

at




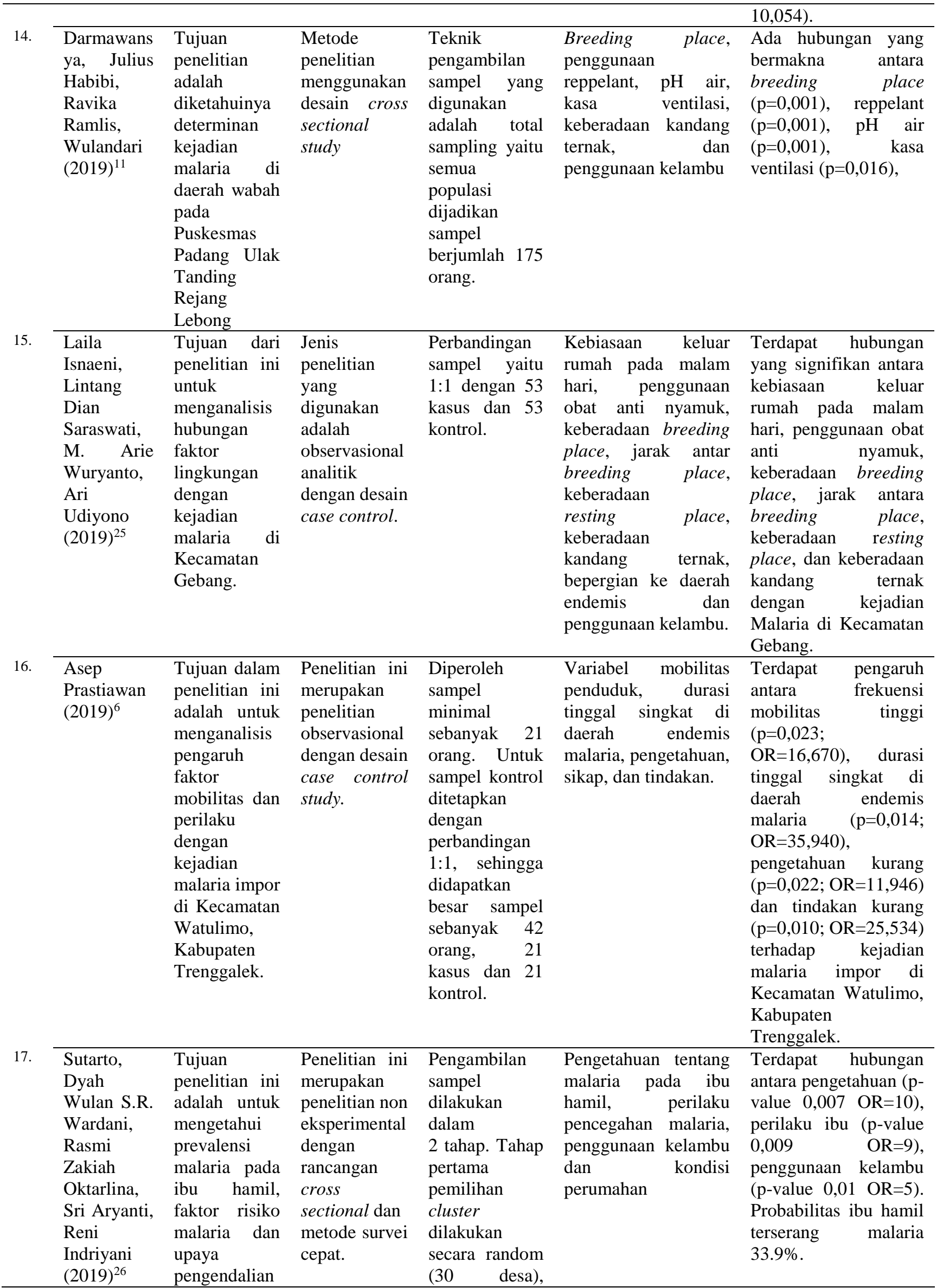




\begin{tabular}{|c|c|c|c|c|c|c|}
\hline \multirow[b]{2}{*}{18.} & & $\begin{array}{l}\text { faktor risiko } \\
\text { malaria di } \\
\text { Kabupaten } \\
\text { Pesawaran } \\
\text { Lampung }\end{array}$ & & $\begin{array}{l}\text { tahap kedua } \\
\text { diambil } \\
\text { sejumlah } \\
\text { responden dari } \\
\text { masing-masing } \\
\text { desa } 7 \text { orang } \\
\text { sehingga } \\
\text { jumlah } \\
\text { responden } 210 \\
\text { orang. }\end{array}$ & & \\
\hline & $\begin{array}{l}\text { Uly } \\
\text { Agustine, } \\
\text { Maria } \\
\text { Endang, } \\
\text { Era Kale, } \\
\text { Emilia } \\
\text { Akoit } \\
(2019)^{27}\end{array}$ & $\begin{array}{l}\text { Tujuan } \\
\text { keseluruhan } \\
\text { adalah untuk } \\
\text { mengeksplora } \\
\text { si } \\
\text { kemungkinan } \\
\text { pencegahan } \\
\text { malaria pada } \\
\text { ibu hamil } \\
\text { dengan } \\
\text { menguji } \\
\text { korelasi antar } \\
\text { variabel. }\end{array}$ & $\begin{array}{l}\text { Penelitian ini } \\
\text { merupakan } \\
\text { penelitian } \\
\text { analitik } \\
\text { dengan desain } \\
\text { penelitian } \\
\text { case control. }\end{array}$ & $\begin{array}{l}\text { Teknik } \\
\text { pengambilan } \\
\text { sampel yang } \\
\text { digunakan } \\
\text { adalah Simple } \\
\text { Random } \\
\text { Sampling. } \\
\text { Jumlah } \\
\text { informan yang } \\
\text { dipilih adalah } \\
23 \text { ibu hamil } \\
\text { yang pernah } \\
\text { menderita } \\
\text { malaria saat } \\
\text { hamil dan } 23 \\
\text { ibu hamil } \\
\text { sebagai } \\
\text { kontrol yang } \\
\text { tinggal di } \\
\text { sekitar ibu } \\
\text { yang pernah } \\
\text { menderita } \\
\text { malaria saat } \\
\text { hamil. }\end{array}$ & $\begin{array}{l}\text { Umur, Paritas ibu } \\
\text { hamil, pendidikan, } \\
\text { pekerjaan, } \\
\text { pengetahuan, } \\
\text { ketersediaan obat } \\
\text { malaria, penggunaan } \\
\text { kelambu } \\
\text { berinsektisida, } \\
\text { pendapatan, tenaga } \\
\text { kesehatan, dukungan } \\
\text { keluarga, dan } \\
\text { ketersediaan } \\
\text { infrastruktur sarana } \\
\text { prasarana. }\end{array}$ & 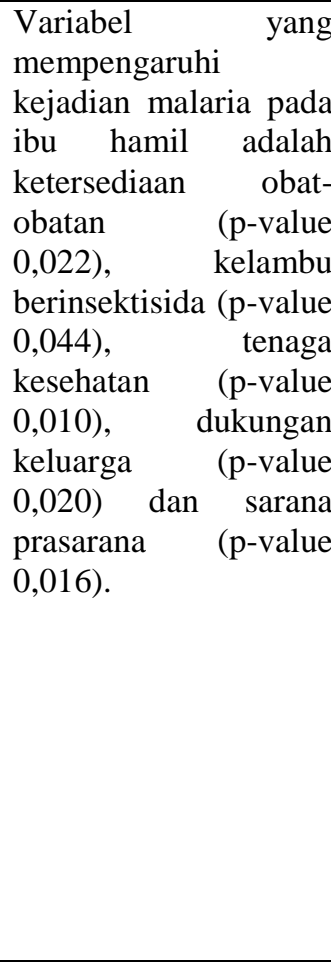 \\
\hline 19. & $\begin{array}{l}\text { Sulistyawat } \\
\text { i, } \\
\text { Rokhmaya } \\
\text { nti, Maririn } \\
\text { Devi } \\
\text { Pradita } \\
(2020)^{28}\end{array}$ & $\begin{array}{l}\text { Penelitian ini } \\
\text { bertujuan } \\
\text { untuk } \\
\text { mengkaji } \\
\text { faktor risiko } \\
\text { potensial dari } \\
\text { aspek sosial } \\
\text { ekonomi } \\
\text { manusia dan } \\
\text { perilaku } \\
\text { manusia } \\
\text { terhadap } \\
\text { kasus } \\
\text { malaria. }\end{array}$ & $\begin{array}{l}\text { Desain } \\
\text { penelitian } \\
\text { observasional } \\
\text {, pendekatan } \\
\text { yang } \\
\text { digunakan } \\
\text { yakni desain } \\
\text { studi case } \\
\text { control. }\end{array}$ & $\begin{array}{l}\text { Jumlah sampel } \\
\text { dalam } \\
\text { penelitian ini } \\
\text { adalah } 68 \\
\text { responden. } \\
\text { Perbandingan } \\
\text { kasus dan } \\
\text { kontrol 1:1 } \\
\text { yaitu } 34 \text { kasus } \\
\text { dan 34 kontrol } \\
\text { di Kecamatan } \\
\text { Banjarmangu }\end{array}$ & $\begin{array}{l}\text { Variabel beraktivitas } \\
\text { diluar rumah pada } \\
\text { malam hari, } \\
\text { kebiasaan } \\
\text { menggantung } \\
\text { pakaian, penggunaan } \\
\text { jaring kawat, tidak } \\
\text { tidur dibawah } \\
\text { kelambu pada malam } \\
\text { sebelumnya, } \\
\text { keberadaan kandang } \\
\text { sapi, pendapatan } \\
\text { bulanan, pendidikan, } \\
\text { jarak ke pelayanan } \\
\text { kesehatan, biaya } \\
\text { transportasi yang } \\
\text { tinggi, dan asuransi }\end{array}$ & $\begin{array}{l}\text { Beraktivitas diluar } \\
\text { rumah pada malam } \\
\text { hari, penggunaan } \\
\text { jaring kawat, tidak } \\
\text { tidur dibawah } \\
\text { kelambu pada malam } \\
\text { sebelumnya, dan biaya } \\
\text { transportasi yang } \\
\text { tinggi berhubungan } \\
\text { terhadap kejadian } \\
\text { malaria. }\end{array}$ \\
\hline 20. & $\begin{array}{l}\text { Masrizal, } \\
\text { Tria } \\
\text { Syananda } \\
\text { Putri, } \\
\text { Imraatul } \\
\text { Hasni } \\
(2020)^{29}\end{array}$ & $\begin{array}{l}\text { Penelitian ini } \\
\text { bertujuan } \\
\text { untuk } \\
\text { menguji } \\
\text { faktor-faktor } \\
\text { risiko } \\
\text { kejadian } \\
\text { malaria } \\
\end{array}$ & $\begin{array}{l}\text { Penelitian ini } \\
\text { merupakan } \\
\text { penelitian } \\
\text { observasional } \\
\text { dengan desain } \\
\text { Studi kasus } \\
\text { kontrol }\end{array}$ & \begin{tabular}{lr}
\multicolumn{2}{l}{ Perbandingan } \\
jumlah & sampel \\
$1: 1 \quad$ dengan \\
jumlah & 62 \\
responden & \\
yang terdiri \\
dari 31 kasus \\
dan 31 kontrol.
\end{tabular} & $\begin{array}{l}\text { Kondisi fisik rumah, } \\
\text { riwayat kunjungan } \\
\text { daerah endemik } \\
\text { malaria, pemakaian } \\
\text { repelen, dan aktivitas } \\
\text { di luar rumah pada } \\
\text { malam hari }\end{array}$ & $\begin{array}{l}\text { Hasil uji statistik } \\
\text { menunjukkan faktor } \\
\text { risiko untuk kejadian } \\
\text { malaria adalah kondisi } \\
\text { fisik rumah }(\mathrm{OR}=3,40 ; \\
\text { CI 1,20-9,20) dan } \\
\text { riwayat mengunjungi } \\
\text { daerah }\end{array}$ \\
\hline
\end{tabular}




\begin{tabular}{|c|c|c|c|c|c|c|}
\hline & & $\begin{array}{l}\text { berdasarkan } \\
\text { kondisi } \\
\text { lingkungan } \\
\text { dan perilaku } \\
\text { masyarakat di } \\
\text { Kota Padang. }\end{array}$ & & & & $(\mathrm{OR}=9$; CI 1,20- 394). \\
\hline 21. & $\begin{array}{l}\text { Nur } \\
\text { Hamdani } \\
\text { N, Kartini, } \\
\text { Misrykordi } \\
\text { ati Mira } \\
(2020)^{7}\end{array}$ & $\begin{array}{l}\text { Tujuan } \\
\text { penelitian ini } \\
\text { untuk } \\
\text { mengetahui } \\
\text { faktor-faktor } \\
\text { yang } \\
\text { berhubungan } \\
\text { dengan } \\
\text { kejadian } \\
\text { Malaria di } \\
\text { wilayah kerja } \\
\text { Puskesmas } \\
\text { Wandai } \\
\text { Distrik } \\
\text { Wandai, } \\
\text { Kabupaten } \\
\text { Intan Jaya } \\
\text { Papua. }\end{array}$ & $\begin{array}{l}\text { Jenis } \\
\text { penelitian } \\
\text { yang } \\
\text { digunakan } \\
\text { adalah } \\
\text { penelitian } \\
\text { kuantitatif } \\
\text { dengan } \\
\text { metode } \\
\text { analitik } \\
\text { observasional } \\
\text { menggunakan } \\
\text { desain case } \\
\text { control. }\end{array}$ & $\begin{array}{l}\text { Jumlah sampel } \\
\text { sebanyak } 96 \\
\text { responden } \\
\text { dengan } \\
\text { perbandingan } \\
\text { kasus kontrol } \\
1: 1 \text {. Sebanyak } \\
48 \text { responden } \\
\text { untuk } \\
\text { kelompok } \\
\text { kasus dan } 48 \\
\text { responden } \\
\text { untuk } \\
\text { kelompok } \\
\text { kontrol yang } \\
\text { diperoleh } \\
\text { dengan } \\
\text { teknik } \\
\text { purposive } \\
\text { sampling. }\end{array}$ & $\begin{array}{l}\text { Keberadaan } \\
\text { ternak, } \\
\text { perindukan } \\
\text { kebiasaan } \\
\text { mengangan }\end{array}$ & 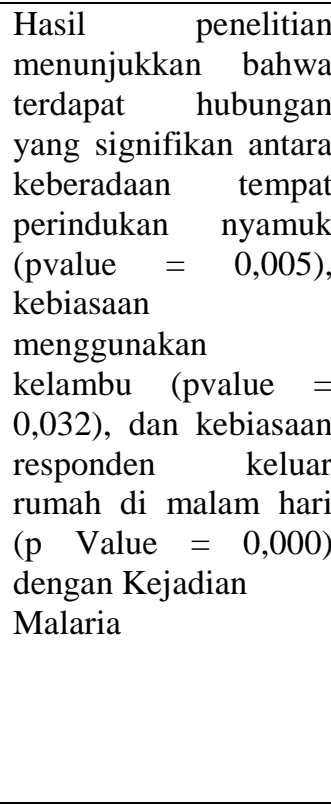 \\
\hline 22. & $\begin{array}{l}\text { Hermanto } \\
\text { Putra, } \\
\text { Muhamma } \\
\text { d Badiran, } \\
\text { Arifah } \\
\text { Devi } \\
\text { Fitriani } \\
(2020)^{30}\end{array}$ & $\begin{array}{l}\text { Tujuan } \\
\text { penelitian ini } \\
\text { untuk } \\
\text { menganalisis } \\
\text { faktor } \\
\text { lingkungan, } \\
\text { faktor } \\
\text { perilaku, } \\
\text { lingkungan } \\
\text { biologis dan } \\
\text { faktor } \\
\text { pelayanan } \\
\text { kesehatan } \\
\text { yang } \\
\text { berpengaruh } \\
\text { terhadap } \\
\text { kejadian } \\
\text { malaria di } \\
\text { wilayah kerja } \\
\text { Puskesmas } \\
\text { Leuser } \\
\text { Kabupaten } \\
\text { Aceh } \\
\text { Tenggara }\end{array}$ & $\begin{array}{l}\text { Penelitian ini } \\
\text { menggunakan } \\
\text { jenis } \\
\text { kuantitatif } \\
\text { dengan } \\
\text { pendekatan } \\
\text { Case Control. }\end{array}$ & $\begin{array}{l}\text { Populasi } \\
\text { dalam } \\
\text { penelitian ini } \\
\text { yaitu yang } \\
\text { menderita } \\
\text { malaria dan } \\
\text { yang tidak } \\
\text { menderita } \\
\text { malaria di } \\
\text { Puskesmas } \\
\text { Leuser } \\
\text { sebanyak } 64 \\
\text { orang kontrol } \\
\text { dan 64 orang } \\
\text { kasus dengan } \\
\text { teknik sample } \\
\text { random } \\
\text { sampling. }\end{array}$ & $\begin{array}{lr}\text { Suhu } & \text { udara, } \\
\text { genangan } & \text { air, } \\
\text { kandang } & \text { hewan, } \\
\text { pencahayaan, dinding } \\
\text { rumah, obat anti } \\
\text { nyamuk, kebiasaan } \\
\text { keluar rumah pada } \\
\text { malam } \\
\text { penyuluhan, } \\
\text { penyemprotan rumah, } \\
\text { dan pengobatan }\end{array}$ & $\begin{array}{lr}\text { Ada pengaruh faktor } \\
\text { genangan air, jarak } \\
\text { rumah } \\
\text { breeding dengan } \\
\text { keberadaan } & \text { place, } \\
\text { hewan, } & \text { dinding } \\
\text { rumah, penggunaan } \\
\text { obat } \\
\text { penyuluhan, nyamuk, } \\
\text { pengobatan } \\
\text { kejadian terhadap } \\
\text { Variabel } \\
\text { dominan } \\
\text { kejadian } \\
\text { adalah genangan air. }\end{array}$ \\
\hline
\end{tabular}

\section{PEMBAHASAN}

Berdasarkan tabel 1, dari 22 jurnal yang masuk dalam penelitian ditemukan 49 variabel secara keseluruhan dengan 36 variabel diantaranya bermakna secara statistik dengan kejadian malaria di Indonesia. Variabel yang berhubungan tersebut dilihat berdasarkan hasil uji statistic perartikel seperti kondisi fisik rumah (langit-langit, dinding rumah, kawat kasa), resting place, breeding place (selokan, genangan air), kebiasaan keluar rumah pada malam hari, penggunaan pakaian panjang pada malam hari, penggunaan kelambu, umur, sosial 
ekonomi, tingkat pendidikan, penggunaan obat anti nyamuk, tingkat pengetahuan, sikap, tindakan, biaya transportasi tinggi, kegiatan penyuluhan malaria, kegiatan bersih lingkungan, pola perilaku pencegahan, lingkungan fisik (suhu, kelembaban, curah hujan, $\mathrm{pH}$ air, ketinggian, penggunaan lahan), keberadaan kandang ternak, kepadatan anopheles. $s p$, jarak breeding place, mobilitas tinggi, riwayat perjalanan ke daerah endemis, durasi tinggal didaerah endemis, ketersediaan obat/dukungan keluarga (bagi ibu hamil), tenaga kesehatan, ketersediaan sarana prasarana kesehatan.

Dari keseluruhan variabel tersebut terdapat faktor yang paling dominan berpengaruh terhadap kejadian malaria berdasarkan kesamaan hasil antar peneliti. Faktor-faktor dominan tersebut adalah penggunaan kelambu (11 artikel), breeding place (9 artikel), keluar rumah pada malam hari ( 9 artikel), dan penggunaan obat anti nyamuk (5 artikel).

\section{Penggunaan Kelambu}

Penggunaan kelambu secara teratur dapat mengurangi kejadian malaria hal tersebut merupaka pernyatan yang tertulis dalam beberapa artikel dan merupakan faktor utama dalam pencegahan kasus malaria. Dalam studi penelitian menyebutkan bahwa apabila seseorang mempunyai kebiasaan tidak menggunakan kelambu pada malam hari akan memiliki probabilitas menderita malaria sebesar 4,2\%. Kebanyakan responden menunjukkan alasan tidak menggunakan kelambu antara lain tidaktersedianya kelambu, merasa panas, kelambu yang dimiliki hanya di pakai sebagian keluarga. ${ }^{21}$

Kebiasaan menggunakan kelambu merupakan upaya yang efektif untuk mencegah dan menghindari kontak antara nyamuk Anopheles sp. dengan orang sehat disaat tidur pada malam hari. Seperti yang diketahui bahwa nyamuk Anopheles $s p$. aktif mencari darah pada malam hari. Menggunakan kelambu yang tidak rusak atau berlubang pada malam hari dapat mencegah atau melindungi dari gigitan nyamuk Anopheles sp. ${ }^{23}$ Penggunaan kelambu merupakan upaya dalam mengurangi risiko nyamuk Anopheles sp. untuk menggigit. Dengan tidak menggigit artinya tidak ada kontak antara manusia dan nyamuk tersebut yang aktif pada malam hari. Sehingga perlu adanya pencegahan kejadian malaria terutama di daerah endemis dengan penggunaan kelambu.

\section{Keberadaan Breeding Place}

Breeding place (tempat perkembangbiakan atau perindukan nyamuk anopheles sp.) dapat berupa selokan atau parit, genangan air di semak, wadah dekat sumur, cekungan wadah pot, wadah tanah liat, wadah sampah dan tempat yang tergenang oleh air di luar rumah atau ruangan.

Berdasarkan hasil uji statistik menyebutkan bahwa seseorang yang tempat tinggalnya berdekatan dengan breeding place berisiko 5,077 kali lebih besar dibanding dengan seseorang yang tempat tinggalnya tidak berdekatan dengan breeding place sehingga disimpulkan bahwa keberadaan breeding place berhubungan dengan kejadian malaria. ${ }^{25}$ Semakin dekat jarak habitat perkembangbiakan dengan rumah maka semakin besar risiko tertular malaria karena genangan air merupakan tempat untuk hidup dan berkembangbiak larva menjadi nyamuk dewasa. ${ }^{22}$ Kegiatan membersihkan sekitar rumah dan mengalirkan genangan air dapat mengurangi risiko perkembangbiakkan nyamuk Anopheles sp. sehingga dapat menekan kepadatan vektor penyebab malaria.

\section{Kebiasaan Keluar Rumah Pada Malam Hari}

Penelitian yang dilakukan di Wilayah Kerja Puskesmas Salaman I, Kabupaten Magelang menunjukkan bahwa masyarakat yang memiliki kebiasaan berada di luar rumah pada malam hari berisiko 2,340 kali lebih besar terkena malaria dibandingkan dengan responden yang tidak memiliki kebiasaan berada di luar rumah pada malam hari. ${ }^{18}$ Kebiasaan berada di luar rumah sampai larut malam, dimana vektor malaria bersifat eksofilik dan eksofagik akan memudahkan gigitan nyamuk. ${ }^{24}$

Kebiasaan keluar pada malam hari merupakan hal yang seharusnya dihindari jika tidak ada upaya pencegahan yang dilakukan seperti penggunaan obat anti nyamuk sebelum keluar rumah ataupun penggunaan pakaian panjang. Malaria umumnya banyak terjadi di wilayah pedesaan dimana karakteristik masyarakatnya senang melakukan aktivitas di luar rumah pada malam hari dengan pakaian pendek. Aktivitas yang dilakukan pada malam hari berupa kegiatan bertegur sapa antar tetangga, berkumpul ataupun bermain disekitar rumah. Kebiasaan keluar rumah adalah perilaku yang memiliki risiko terjadinya kontak antara manusia dengan nyamuk Anopheles sp. sebagai vektor malaria.

\section{Penggunaan Obat Anti Nyamuk}

Risiko kejadian malaria yang selanjutnya adalah penggunaan obat anti nyamuk. Penelitian yang dilakukan di Puskesmas Dawai Kecamatan Yapen Timur Kabupaten Kepulauan Yapen menunjukkan bahwa responden yang tidak menggunakan obat anti nyamuk malaria memiliki risiko kejadian malaria 3.208 kali lebih tinggi 
daripada responden yang tidak menggunakan obat anti nyamuk. Responden yang tidak menggunakan obat anti nyamuk mengalami gigitan nyamuk pada malam hari. ${ }^{21}$

Salah satu yang menjadi alasan masyarakat memakai obat anti nyamuk adalah karena kurangnya jumlah kelambu yang dibagikan. Jenis obat nyamuk yang paling banyak di pakai adalah obat nyamuk bakar. Pemakaian obat anti nyamuk bakar hanya bersifat sementara karena lama-kelamaan akan menyebabkan nyamuk kebal terhadap obat anti nyamuk selain itu obat anti nyamuk bakar dapat mempengaruhi kesehatan. Namun beberapa responden yang tidak menggunakan obat anti nyamuk memliki alasan karena tidak suka asap yang menyebabkan sesak napas dan sudah memiliki kelambu. Penggunaan obat anti nyamuk mencegah gigitan nyamuk dan penularan penyakit malaria jika tidak digunakan secara terus menerus. Dengan mempertimbangkan aspek kesehatan, masyarakatlebih dianjurkan menggunakan kelambu sebagai pelindung pada saat malam hari.

Berdasarkan tabel 2, maka rata-rata jumlah variabel yang diteliti perartikel adalah sebesar 7.36 (7 variabel) sedangkan jumlah variabel yang bermakna secara statistik sebesar 4.09 (4 variabel). Artinya dari 7 variabel yang diteliti lebih dari 50\% itu berhubungan sevara signifikan dengan kejadian malaria. Nilai minimal variabel terkecil yang diteliti berjumlah 2 dan variabel yang bermakna secara statistik 2, sedangkan nilai terbesar variabel yang diteliti adalah 14 dan variabel yang bermakna secara statistik adalah 8 .

\section{KESIMPULAN}

Penelitian ini menyimpulkan bahwa faktor lingkungan, perilaku, pengetahuan, sikap, tindakan pencegahan, sosial ekonomi, demografis berhubungan dengan kejadian malaria. Dari 22 artikel yang diteliti berdasarkan studi literatur terdapat faktor risiko dominan sebagai penyebab kejadian malaria di Indonesia penelitian ini adalah penggunaan kelambu, keberadaan breeding place, kebiasaan keluar rumah pada malam hari, dan penggunaan obat anti nyamuk. Diharapkan masyarakat di daerah endemis malaria untuk dapat menggunakan kelambu pada malam hari, selalu membersihkan genangan air disekitar rumah, menghindari aktivitas keluar pada malam hari jika tidak diperlukan, serta dapat menghindari gigitan nyamuk dengan penggunaan obat anti nyamuk.

\section{UCAPAN TERIMA KASIH}

Ucapan terima kasih yang berlimpah diberikan kepada Bapak Dr. Ir. Mursid Raharjo, M.Si dan Bapak Dr. Nurjazuli, S.K.M., M.Kes selaku dosen pembimbing 1 dan pembimbing 2 di Universitas Diponegoro yang telah memberikan arahan dan bimbingan dalam penyusunan artikel review ini.

\section{DAFTAR PUSTAKA}

1. World Health Organization. World Malaria Report 2020. from WHO Press. 2020

2. Herdiana H, Cotter C, Coutrier FN, Zarlinda I, Zelman BW, Tirta YK, et al. Malaria risk factor assessment using active and passive surveillance data from Aceh Besar, Indonesia, a low endemic, malaria elimination setting with Plasmodium knowlesi, Plasmodium vivax, and Plasmodium falciparum. Malaria Journal. 2016;1-15.

3. Kementerian Kesehatan Republik Indonesia. Profil Kesehatan Indonesia Tahun 2016. Kementerian Kesehatan Republik Indonesia. 2016. 186-187p.

4. Kementerian Kesehatan Republik Indonesia. Profil Kesehatan Indonesia Tahun 2019. Kementerian Kesehatan Republik Indonesia. 2019

5. Kementerian Kesehatan Republik Indonesia. Laporan Kinerja Tahun 2019. Kementerian Kesehatan Republik Indonesia. 2020

6. Prastiawan A. Pengaruh Faktor Mobilitas Dan Perilaku Terhadap Kejadian Malaria. J Kesehat Lingkung. 2019;11(2).

7. Hamdani Nur, Kartini MM. Faktor - Faktor Yang Berhubungan Dengan Kejadian Malaria Di Wilayah Kerja Puskesmas Wandai Distrik Wandai Kabupaten Intan Jaya Papua. J Promot Prev. 2020;2(2):1-7.

8. Manumpa S. Pengaruh Faktor Demografi dan Riwayat Malaria Terhadap Kejadian Malaria. Jurnal Berkala Epidemiologi. 2015;4:338-48.

9. Unun Budiarti M. Gusti Talombo, Muh. Ardi Munir GL. Analisis Faktor Risiko Utama Terhadap Kejadian Malaria Di Wilayah Puskesmas Kampung Baru Luwuk Tahun 20132015. J Ilmu Kedokt. 2018;5(2).

10. Watmanlusy E, Raharjo M. Analisis Spasial Karakteristik Lingkungan dan Dinamika Kepadatan Anopheles sp . Kaitannya Dengan Kejadian Malaria di Kecamatan Seram Maluku. J Kesehat Lingkung Indones. 2019;18(1):12-8.

11. Sucipto, C. D. 2015. Manual Lengkap Malaria. Penerbit : Gosyen Publishing, Yogyakarta. 
12. Darmawansyah, Julius Habibi, Ravika Ramlis W. Determinan Kejadian Malaria (Kajian Epodemiologi di Daerah Wabah). J Ilmu Kesehat Masy. 2019;08(03):136-42.

13. Mardiyantoro N. Literatur Review. Metodologi Penelitian. 2019;1-18.

14. Pickering, C., Grignon, J., Steven, R., Guitart, D. and Byrne. J. Publishing not perishing: How research students transition from novice to knowledgeable using systematic quantitative literature reviews. Studies in Higher Education. 2015;40:1756-1769

15. Pratiwi Ika Noviarti, Tri Joko NAYD. Hubungan Faktor Lingkungan Fisik Dan Perilaku Penghuni Rumah Dengan Kejadian Penyakit Malaria Di Wilayah Kerja Puskesmas Kokap Ii, Kabupaten Kulon Progo, Daerah Istimewa Yogyakarta. Jurnal Kesehatan Masyarakat. 2016;4.

16. Fadjar Harry Wiwoho, Suharyo Hadisaputro AS. Faktor Risiko Kejadian Malaria di Puskesmas Cluwak dan Puskesmas Dukuhseti Kabupten Pati. J Epidemiol Kesehat Komunitas. 2016;1(1):1-8.

17. Ahmad Faizal Rangkuti, Sulistyani NEW. Faktor Lingkungan dan Perilaku yang Berhubungan dengan Kejadian Malaria di Kecamatan Panyabungan Mandailing Natal Sumatera Utara. BALABA. 2017;13(1):1-10.

18. Wardah, Nurjazuli HLD. Analisis Spasial Faktor Lingkungan Dengan Kejadian Malaria Di Wilayah Kerja Puskesmas Salaman I, Kabupaten Magelang. Jurnal Kesehatan Masyarakat. 2017;5(293):911-9.

19. Darmiah, Baserani, Abdul Khair, Isnawati YS. Hubungan tingkat pengetahuan dan pola perilaku dengan kejadian malaria di Kabupaten Katingan Provinsi Kalimantan Tengah Relationship of knowledge level and behavioral pattern with malaria incidence in Katingan Regency Central Kalimantan Province. J Heal Epidemiol Commun Dis. 2018;3(2):36-41.

20. Abner Fritz Watofa, Adi Heru Husodo, Sudarmadji OS. Risiko Lingkungan Fisik Terhadap Kejadian Malaria Di Wilayah Danau Sentani , Kabupaten Jayapura , Provinsi Papua. J Mns dan Lingkung. 2017;24(1):31-8.

21. Sarjatno AR, Rantetampang AL, Makaba S,
Mallongi A. Risk Factors of Malaria Incidence in Working Areas Puskesmas Dawai District East Yapen Sub Province Kepulauan Yapen. Int J Sci Healthc Res. 2018;3(4):34-45.

22. Nababan R, Umniyati SR. Faktor lingkungan dan malaria yang memengaruhi kasus malaria di daerah endemis tertinggi di Jawa Tengah: analisis sistem informasi geografis. BKM J Community Med Public Heal. 2018;34(1):11-8.

23. Sepriyani , Andoko AAP. Analisis Faktor Risiko Kejadian Malaria Di Wilayah Kerja Puskesmas Biha Kabupaten Pesisir Barat. J Kesmas (Kesehatan Masyarakat) Khatulistiwa. 2018;77-87.

24. Eyanoer PC. Dominant risk factors for malaria at Puskesmas Labuhan Ruku, Talawi Dominant risk factors for malaria at Puskesmas Labuhan Ruku, Talawi Batu Bara, Indonesia. IOP Conf Ser Earth Environ Sci Pap. 2018;0-5.

25. Laila Isnaeni, Lintang Dian Saraswati, M. Arie Wuryanto AU. Faktor Perilaku Dan Faktor Lingkungan Yang Berhubungan Dengan Kejadian Malaria Di Wilayah Kerja Puskesmas Gebang Kabupaten Purworejo. J Kesehat Masy. 2019;7(2):31-9.

26. Sutarto, Wardani DWSR, Oktarlina RZ, Aryanti $\mathrm{S}$, Indriyani R. Risk Factors for Malaria in Pregnant Women. J Kesehat Masy. 2019;14(3):332-9.

27. Agustine U, Endang M, Kale E, Akoit E. Risk Factors of Malaria Events among Pregnant Women in East Sumba Regency, Indonesia. Res Sq. 2019;

28. Sulistyawati S, Rokhmayanti R, Pradita MD. Potential Risk Factor for Malaria Infection in Banjarnegara , Indonesia: A Potential Risk Factor for Malaria Infection in Banjarnegara , Indonesia : A Matched Case-control Study. Int J Trop Dis Heal. 2020;41(5):28-35.

29. Masrizal Masrizal, Tria Syananda Putri IH. Environmental And Behavioral Conditions That Affect Malaria Events In Padang CitY. J Berk Epidemiol. 2020;8(2):1-8.

30. Putra H, Badiran M, Fitriani AD. Associated Factors The malaria Prevalence In The Leuser Primary Health Service Area Of Southeast Aceh. Jurnal Komunitas Kesehatan Masyarakat. 2020;1:2. 